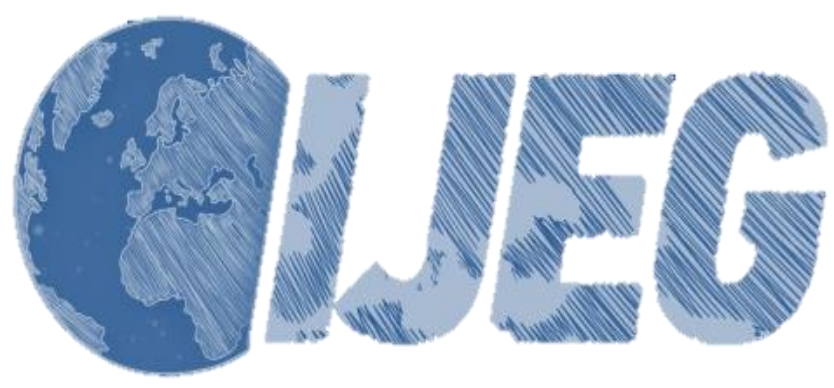

International Journal of Engineering and Geosciences (IJEG), Vol; 4, Issue; 3, pp. 129-140, October, 2019, ISSN 2548-0960, Turkey, DOI: 10.26833 ijeg. 525020

\title{
POSITIONING BUILDINGS ON A ZONING ISLAND TO PROVIDE MAXIMUM SHADING: A CASE STUDY
}

\author{
Hüseyin İnce ${ }^{1}$ and Nuri Erdem ${ }^{2 *}$ \\ ${ }^{1}$ Vocational School of Higher Education for Mapping and Land Survey, Hitit University, Çorum, Turkey, \\ (huseyinince@ hitit.edu.tr); ORCID 0000000161185502 \\ ${ }^{2 *}$ Engineering Faculty, Department of Geomatics Engineering, Osmaniye Korkut Ata University, Osmaniye, Turkey \\ (nurierdem@ osmaniye.edu.tr); ORCID 0000-0002-1850-4616
}

*Corresponding Author, Received: 09/02/2019, Accepted: 14/06/2019

\begin{abstract}
Because summer days are long, and the weather is too hot, people desire shady spaces to escape the overwhelming effect of the sun. To keep buildings and open-air environments in the shade, a suitable building location design may be created at the planning stage. Positioning of buildings and recreation areas in the maximum amount of shade is closely dependent on the location of the buildings to be built, the distance between the buildings, the time of the day and the sun angles at a particular hour. It was found necessary to carry out this study, since no study was found to be carried out regarding the positioning of buildings in the maximum amount of shade. For buildings to be built in residential areas, separate or block arrangements are applied. This study discusses a building to be built on a reconstruction island in Adana in the Eastern Mediterranean Region of Turkey. First of all, the shading effects of the buildings adjacent to the building in a parcel were examined in detail based on various positions of the façades of the building and different values of the solar azimuth. As a result of the study, the positioning of the buildings for providing the maximum shading was investigated. If the front and rear façades of the buildings were located in the west-east direction, according to the positioning of the buildings in the north-south direction, the front and rear façades would be exposed to less sunlight and more shade. In $\mathrm{h}=$ \pm 6 sun hours, the façades of buildings in the parcels facing the north were under the influence of the sun rays coming from the side, and the rear façades of the buildings were in the shade.
\end{abstract}

Keywords: Sun Angles, Shading, Building Shading Positions, Energy Efficiency 


\section{INTRODUCTION}

In Turkey, because summer days are long and the weather is too hot, shady places are desired for getting rid of the sun's overwhelming effect. In order to ensure that buildings or open-air rest areas are kept in the shade, they can be designed with buildings or recreation areas at the planning stage (Kuşak and Küçükali, 2019; Ekercin et al., 2019). Positioning the specified spaces in the maximum amount of shade is closely related to the location of the buildings, the distance between the buildings, the sun's azimuth angle and the solar zenith angle, as well as the time of the day and the sun declination angle at that time.

The locations of the buildings or recreational areas to be built on parcels in a reconstruction island are designed in a parceling plan. In studies on the subject in practice (Yüceer, 2010; Yüceer, 2011; Selim and Demir, 2019), external shade element designs were suggested, and the shape and yield of external shade elements in Adana in the Eastern Mediterranean Region of Turkey were investigated with shade line charts. The shape and size of the shading elements required for the four main directions of a $\mathrm{P}$ window sample of $120 / 140$ size as the shading element were specified.

This study was based on the height of five-story buildings as a shading element in a reconstruction island in Adana. In the parcel where five-story buildings are located in the neighboring garden, in the side garden, in the back garden and in the front garden, the warmest days of the year, from May 1st to October 1st, were taken into consideration for the period from local lunch time to \pm 6 solar hours. The locations where the structures to be constructed in a discrete structure order to be kept in the shade were investigated by considering the average latitude of the region and the hour angles of sunrise and sunset in the specified period. It was found necessary to carry out this study because previous studies (Yeang, 1995; Oktay, 2004; Farr, 2008) did not report on this particular topic.

\section{GARDEN DISTANCES AND ROAD WIDTHS ACCORDING TO THE TYPE \\ RECONSTRUCTION REGULATION}

For buildings to be built in the settlement areas, a separate order or block order is applied. For a building to be built in a parcel, according to the Planned Areas Type Reconstruction Regulation in force, garden distances are accounted for. In the Implemented Planned Areas according to the provisions of the Type Reconstruction Regulation, front garden distance, side garden distance, neighboring garden distance and back garden distance are indicated as follows:

- In buildings with up to 4 floors (including 4 floors); front garden distance $=5 \mathrm{~m}$., side garden distance $=$ $5 \mathrm{~m}$., neighboring garden distance $=3 \mathrm{~m}$.

- In buildings with up to 5 floors (including 5 floors); front garden distance $=5 \mathrm{~m}$., side garden distance $=$ $5 \mathrm{~m}$., neighboring garden distance $=0.50 \mathrm{~m}$ for each floor. After 4 floors, the distance is increased.

- While examining the shading effect of buildings in for building on a reconstruction island opposite another building, there is a need for road width between buildings.
On the subject of the Type Reconstruction Regulation;

- Width of road in 3-storey buildings (excluding basement): $7.00-10.00 \mathrm{~m}$

- Width of road in 4-storey buildings (excluding basement): $10.00-12.00 \mathrm{~m}$.

- Width of road in 5-storey buildings (excluding basement): $12.00-15.00 \mathrm{~m}$, this cannot be less, and provisions are included.

\section{SOLAR ANGLES}

While positioning structures to benefit from sunlight, incidence direction angles of sun rays (azimuth angles) are utilized. The azimuth angle of the sun consist of the latitude of the construction site $(\varphi)$, the declination angle of the sun for a particular day of the year $(\delta)$ and the angle of sunrise and sunset according to the local noon. These angles are called azimuth (Olgyay, 1957; Soler and Oteiza, 1997; Abood, 2015; Som and Pathak; 2015).

Latitude (angle) $\varphi$ : It is the angle of the line which combines the aboveground $\mathrm{N}$ point to the centrosphere, with the equatorial plane. It is marked with a (+) from the Equator to the north and with a (-) to the south.

Hour Angle (h): It is the angle between the line which combines the longitude of the considered point on earth with the centrosphere and the longitude indicated by sun rays. The hour angle is calculated from the "solar noon", when the longitude of the sun and the longitude of the point which is being considered are the same. The difference is marked with a (-) for before the local noon and with a (+) for after the local noon. Every one-hour time difference is considered as an hour angle of $15^{\circ}$.

Declination Angle $(\delta)$ : It is the angle of sun rays to the equatorial plane (Figure 1). This angle results from the $23^{\circ} 27^{\prime}$ degrees of difference between the rotational axis of the world and the normal of the orbital plane. The absolute value in the solstices is maximum (June 21 summer solstice $=+23^{\circ} .45$, December 22 winter solstice $\left.=-23^{\circ} .45\right)$. The declination angle is obtained from the equation:

$\delta=23^{\circ} .45 \sin \left(360\left(\frac{n+284}{365}\right)\right)$

Here, $\mathrm{n}$ is the number of days.

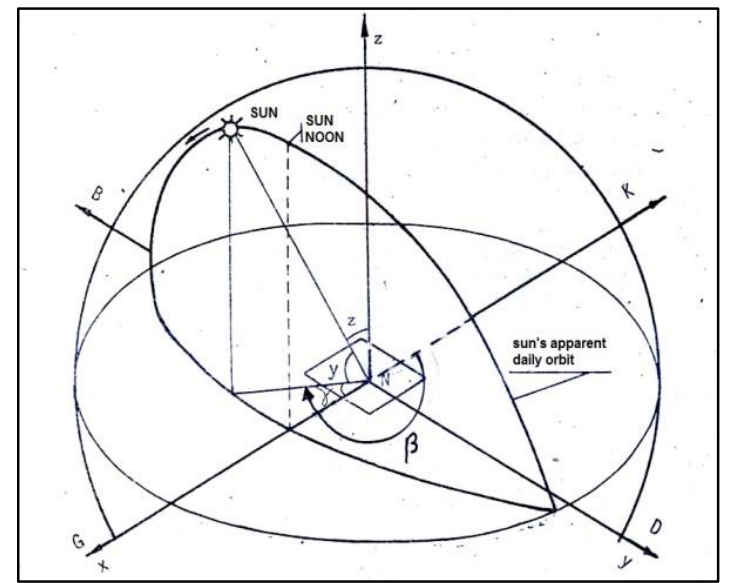


Figure 1. Schematic of the Solar Zenith Angle, Elevation and Azimuth Angle, at the Spherical Triangle from a Point on Earth of N (Abood, 2015)

Zenith angle (z): It is the angle between direct sun rays and the normal of the horizontal plane (Figure 1). At sunrise and sunset, $z=90^{\circ}$. The zenith angle is obtained with the formula below.

$\operatorname{Cos} \mathrm{z}=\cos \delta \cos \varphi \cos \mathrm{h}+\sin \delta \sin \varphi$

Solar elevation angle (y): It is the angle of the horizontal rays of the sun. As seen in Figure $1, \mathrm{z}+\mathrm{y}=90^{\circ}$. The solar elevation angle is obtained with the formula: $\mathrm{y}=90-\mathrm{z}$.

Solar azimuth angle $(\beta)$ : This angle represents the deviation of sun rays' rotation in reference to the clockwise direction of north (Figure 1). $\beta$ as follows;

Before the local noon (in degrees), $\beta=180^{\circ}-\gamma^{\circ}$ (or in grade $\beta=200-\gamma^{\mathrm{G}}$ )

After the local noon (in degrees), $\beta=180^{\circ}+\gamma^{\circ}$ (or in grade $\beta=200+\gamma^{\mathrm{G}}$ )

$\operatorname{Cos} \gamma=\frac{\cos \delta \cos \varphi \cosh -\sin \delta \cos \varphi}{\cos y}$

\section{CALCULATION OF SUN ANGLES AND SHADING LENGTHS FOR THE EASTERN MEDITERRANEAN REGION}

In order to determine the shading position of a building in sunny weather in the Eastern Mediterranean region, there is a need for sunrise and sunset angles, solar declination angle, solar zenith angle and solar azimuth angle at a specified time interval.

In the calculation of the solar zenith angle, the solar elevation angle and the solar azimuth angle, the following elements were firstly calculated:

- The values of 1,15 and 22 of each month from 1 May to 1 October were calculated by using correlation (1) for solar declination.

- The Eastern Mediterranean Region is located between $32^{\circ} 56^{\prime}$ and $36^{\circ} 42^{\prime}$ in longitudes and $35^{\circ}$ $52^{\prime}$ and $38^{\circ} 00^{\prime}$ in latitudes. The value $\varphi=37^{\circ}$ for Adana was used as the average value representing the region.

- The hour angles of sunrise and sunset were obtained from the information on calendars showing the specified time in Adana, Hatay, Osmaniye and Mersin. In the examination of the four aforementioned provinces, it was seen that there was a difference of 5-6 minutes between their times of sunrise, sunset and midday time on 21 June. Therefore, from 1 May to 1 October, the clock angles of sunrise and sunset were used for Adana, and the results are shown in Table 1.

Table 1. Time in Adana, watch angels of Sunrise and Sunset

\begin{tabular}{|c|c|c|c|c|c|c|}
\hline \multirow{2}{*}{$\begin{array}{c}\text { Days of } \\
\text { Year }\end{array}$} & \multirow{2}{*}{$\mathrm{n}$} & \multicolumn{3}{|c|}{ Solar Times } & \multicolumn{2}{c|}{ Sun Watch Angle } \\
\cline { 3 - 7 } & & Sunrise & Noon & Sunset & Sunrise (h) & Sunset (h) \\
\hline 1 May & 121 & $5: 37$ & $12: 43$ & $19: 36$ & $12: 43-5: 37=7: 06$ & $19: 36-12: 43=6: 53$ \\
\hline 15 May & 135 & $5: 24$ & $12: 42$ & $19: 48$ & $12: 42-5: 24=7: 18$ & $19: 48-12: 42=7: 06$ \\
\hline 1 Jun & 152 & $5: 14$ & $12: 43$ & $19: 59$ & $12: 43-5: 14=7: 29$ & $19: 59-12: 43=7: 16$ \\
\hline 22 Jun & 172 & $5: 12$ & $12: 48$ & $20: 11$ & $12: 48-5: 12=7: 36$ & $20: 11-12: 48=7: 23$ \\
\hline 1 July & 182 & $5: 16$ & $12: 49$ & $20: 09$ & $12: 49-5: 16=7: 33$ & $20: 09-12: 49=7: 60$ \\
\hline 15 July & 196 & $5: 24$ & $12: 52$ & $20: 07$ & $12: 52-5: 24=7: 28$ & $20: 07-12: 52=7: 15$ \\
\hline 1 Aug & 213 & $5: 37$ & $12: 51$ & $19: 54$ & $12: 51-5: 37=7: 1$ & $19: 54-12: 51=7: 03$ \\
\hline 15 Aug & 227 & $5: 49$ & $12: 50$ & $19: 40$ & $12: 50-5: 49=7: 01$ & $19: 40-12: 50=6: 50$ \\
\hline 1 Sept & 244 & $6: 03$ & $12: 46$ & $19: 17$ & $12: 46-6: 03=6: 43$ & $19: 17-12: 46=6: 31$ \\
\hline 15 Sept & 258 & $6: 14$ & $12: 41$ & $18: 56$ & $12: 41-6: 14=6: 27$ & $18: 56-12: 41=6: 15$ \\
\hline 1 Oct & 273 & $6: 27$ & $12: 36$ & $18: 32$ & $12: 36-6: 27=6: 09$ & $18: 32-12: 36=5: 56$ \\
\hline
\end{tabular}

When Table 1 is examined, it is seen that the sun hour angles of sunrise and sunset in Adana, determined on the selected days of the year, changed between 5.56 and 7.60 hours, and the value $h= \pm 6$ was considered in the study. For the times indicated in Table 1, the solar declination angles, solar zenith angles and solar elevation angles corresponding to the solar hour angles from $h=0$ to $h=$ \pm 6.0 were calculated by the aforementioned correlations and are shown in Table 2. The $\gamma$ angles required for the calculation of the azimuth angle of the sun were calculated by considering the angles in Table 2 and are shown in Table 3.

A mathematical error $(\cos h>1.0)$ was generated in the calculation of for $h= \pm 1$ in Table 3 . For the calculation of the solar azimuth angles for $h= \pm 1$, half of the calculated in the interval of $h= \pm 2$ were taken. 
Table 2. Solar zenith angles and sun height angles from 1 May to 1 October in Adana (in grad units) (italic figures are solar height angle values)

\begin{tabular}{|c|c|c|c|c|c|c|c|c|}
\hline \multirow{2}{*}{$\begin{array}{c}\text { Days of } \\
\text { Year }\end{array}$} & \multirow{2}{*}{$\begin{array}{l}\text { Declinations } \\
\text { Angle } \delta^{\circ}\end{array}$} & \multicolumn{7}{|c|}{ Hour Angels } \\
\hline & & 0 & 1 & 2 & 3 & 4 & 5 & 6 \\
\hline \multirow{2}{*}{1 May } & \multirow{2}{*}{14.9009} & 24.5546 & 28.6786 & 38.4445 & 50.5934 & 63.6360 & 76.9298 & 90.1082 \\
\hline & & 75.4554 & 71.3214 & 61.5555 & 49.4066 & 36.3640 & 23.0702 & 9.8918 \\
\hline \multirow{2}{*}{15 May } & \multirow{2}{*}{18.7919} & 20.2312 & 24.9527 & 35.4850 & 49.0452 & 61.2416 & 74.5263 & 87.5796 \\
\hline & & 79.7688 & 75.0477 & 64.5150 & 50.9548 & 38.7584 & 25.4737 & 12.4204 \\
\hline \multirow{2}{*}{1 Jun } & \multirow{2}{*}{22.0396} & 16.6226 & 22.0001 & 33.2184 & 46.0796 & 59.3538 & 72.5864 & 85.4982 \\
\hline & & 83.3774 & 77.9999 & 66.7816 & 53.9204 & 40.6462 & 27.4136 & 14.5018 \\
\hline \multirow{2}{*}{$21 \mathrm{Jun}$} & \multirow{2}{*}{23.4498} & 15.0558 & 20.7799 & 32.3028 & 45.2774 & 58.5684 & 71.7648 & 84.6040 \\
\hline & & 84.9442 & 79.2201 & 67.6972 & 54.7226 & 41.4316 & 28.2352 & 15.3960 \\
\hline \multirow{2}{*}{1 July } & \multirow{2}{*}{23.1205} & 15.4217 & 21.0609 & 32.5126 & 45.4618 & 58.7499 & 71.9554 & 84.8122 \\
\hline & & 84.5783 & 78.9391 & 67.4874 & 54.5382 & 41.2501 & 28.0446 & 15.1878 \\
\hline \multirow{2}{*}{15 July } & \multirow{2}{*}{21.5173} & 17.2030 & 22.4625 & 33.5687 & 46.3850 & 59.6501 & 72.8940 & 85.8309 \\
\hline & & 82.7970 & 77.5375 & 66.4313 & 53.6150 & 40.3499 & 27.1060 & 14.1691 \\
\hline \multirow{2}{*}{1 Aug } & \multirow{2}{*}{17.9132} & 21.2076 & 25.7785 & 36.1321 & 48.6033 & 61.7703 & 75.0618 & 88.1436 \\
\hline & & 78.7924 & 74.2215 & 63.8679 & 51.3967 & 38.2297 & 24.9382 & 11.8524 \\
\hline \multirow{2}{*}{15 Aug } & \multirow{2}{*}{13.7836} & 25.7960 & 29.7767 & 39.3356 & 51.3597 & 64.3479 & 77.6344 & 90.8402 \\
\hline & & 74.2040 & 70.2233 & 60.6644 & 48.6403 & 35.6521 & 22.3656 & 9.1598 \\
\hline \multirow{2}{*}{$1 \mathrm{Sept}$} & \multirow{2}{*}{7.7246} & 32.5282 & 35.8827 & 44.4237 & 55.7465 & 68.3748 & 81.5536 & 94.8447 \\
\hline & & 67.4718 & 64.1173 & 55.5763 & 44.2535 & 31.6252 & 18.4464 & 5.1553 \\
\hline \multirow{2}{*}{$15 \mathrm{Sept}$} & \multirow{2}{*}{2.2169} & 38.6479 & 41.5859 & 49.3399 & 60.0163 & 72.2447 & 85.2368 & 98.5178 \\
\hline & & 61.3521 & 58.4141 & 50.6601 & 39.9837 & 27.7553 & 14.7632 & 1.4822 \\
\hline \multirow{2}{*}{$1 \mathrm{Oct}$} & \multirow{2}{*}{-4.2155} & 45.7950 & 48.3589 & 55.3274 & 65.2643 & 76.9643 & 89.6472 & \\
\hline & & 54.2050 & 51.6411 & 44.6726 & 34.7357 & 23.0357 & 10.3528 & \\
\hline
\end{tabular}

In obtaining the azimuth angles of the sun, calculation was made by using the formulae (3) and (4) based on the values in Table 3 .

Table 3- The $\gamma$ angles used for calculating solar azimuth angles for Adana (in grad units)

\begin{tabular}{|c|c|c|c|c|c|c|c|}
\hline \multirow{2}{*}{$\begin{array}{c}\text { Days of } \\
\text { Year }\end{array}$} & \multicolumn{7}{|c|}{ Hour Angles } \\
\cline { 2 - 8 } & $\mathrm{h}=0$ & $\mathrm{~h}=1$ & $\mathrm{~h}=2$ & $\mathrm{~h}=3$ & $\mathrm{~h}=4$ & $\mathrm{~h}=5$ & $\mathrm{~h}=6$ \\
\hline 1 May & $0^{\mathrm{g}} .00$ & 14.2030 & $28^{\mathrm{g}} .0464$ & 63.0901 & 82.2809 & 96.9353 & 110.0134 \\
\hline 15 May & 0.00 & 16.3265 & 32.6536 & 67.4510 & 85.5846 & 99.8742 & 112.6638 \\
\hline 1 Jun & 0.00 & 18.6540 & 37.3080 & 70.3266 & 88.4969 & 102.3988 & 114.8935 \\
\hline 22 Jun & 0.00 & 19.7860 & 39.5719 & 71.9288 & 89.8064 & 103.5159 & 115.8671 \\
\hline 1 July & 0.00 & 19.5150 & 39.0299 & 71.5494 & 89.4981 & 103.2539 & 115.6395 \\
\hline 15 July & 0.00 & 18.2538 & 36.5076 & 69.7481 & 88.0188 & 101.9883 & 114.5337 \\
\hline 1 Aug & 0.00 & 15.7620 & 31.5238 & 65.9703 & 84.8211 & 99.2025 & 112.0634 \\
\hline 15 Aug & 0.00 & 13.4532 & 26.9063 & 62.0829 & 81.3685 & 96.1081 & 109.2561 \\
\hline 1 Sept & 0.00 & 11.0117 & 22.0234 & 57.1551 & 76.6859 & 91.7437 & 105.1723 \\
\hline 15 Sept & 0.00 & 9.6478 & 19.2956 & 53.3778 & 72.7903 & 87.9399 & 101.4826 \\
\hline 1 Oct & 0.00 & 8.9107 & 17.8214 & 49.6840 & 69.6261 & 83.6685 & \\
\hline
\end{tabular}

\subsection{Calculation of Shading Lengths According to Zenith Angles in the Azimuth Angle Direction}

4.1.1. Calculation of distance between neighboring buildings in the direction of the solar azimuth angle

The sun's rays reach a certain location on earth in the direction of the solar azimuth angle. The shading of a building occurs in the direction of the sun's azimuth angle (Mcmullan, 1990; Ok, 1992; Atabek, 1996; Capeluto et al., 2003).

According to the Planned Areas Type Reconstruction Regulation for 5-storey buildings, the specified neighboring garden distance is $3.5 \mathrm{~m}$, back garden distance is $7.75 \mathrm{~m}$, side garden distance is $5 \mathrm{~m}$, and front garden distance is $5 \mathrm{~m}$.
The horizontal distance between the directions perpendicular to the surfaces of two neighboring buildings;

Neighboring garden distance $=7.00 \mathrm{~m}$, back garden distance $=15.50 \mathrm{~m}$, side garden distance + road width $=$ $17.00 \mathrm{~m}$, and front garden distances + road width $=22.50$ $\mathrm{m}$.

The symbols $X_{K}, X_{\mathrm{A}}, X_{\mathrm{O}}, X_{\mathrm{Y}}$ in the Figures were defined as follows in the direction of the solar azimuth angle.

$\mathrm{X}_{\mathrm{K}}$ : the horizontal distance between buildings in the neighboring garden,

$\mathrm{X}_{\mathrm{A}}$ : the horizontal distance between buildings in the back garden,

$\mathrm{X}_{\mathrm{o}}$ : the horizontal distance between buildings in the front garden, 
$\mathrm{X}_{\mathrm{Y}}$ : the horizontal distance between buildings in the side garden.

The horizontal distance in the garden, considering the sum of the aforementioned distances and angles) (Fig. 2 (a), (b)) is calculated with the following relations:

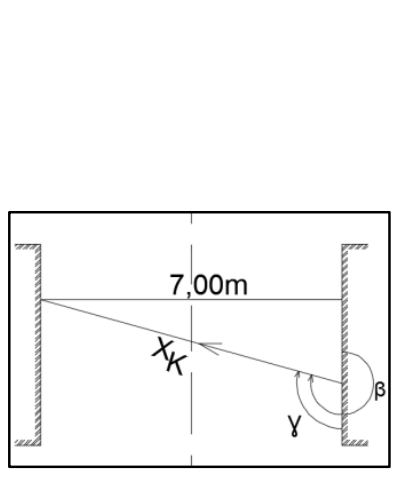

a)

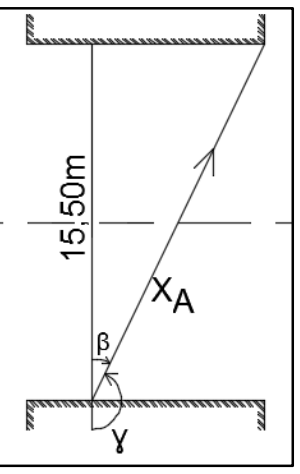

b)
Figure 2- Horizontal distance between neighboring buildings in the direction of the solar azimuth angle.

$\mathrm{X}_{\mathrm{K}}=7.00 / \sin \gamma$ for buildings in neighboring gardens (7)

$\mathrm{X}_{\mathrm{A}}=15.50 / \sin \gamma$ for buildings in back gardens (8)

$\mathrm{X}_{\ddot{O}}=22.50 / \sin \gamma$ for buildings in front gardens (9)

For buildings in side gardens, $X Y=17.00 / \sin \gamma$ (10)

4.1.2. Calculation of Shading Length According to Solar Zenith Angles

When the sun's rays of $z_{1}$ and $z_{2}$ at sunny times at different times (or at elevation angles of $\mathrm{y}_{1}$ and $\mathrm{y}_{2}$ ) (Figure 3) pass through the point $\mathrm{A}$ of a building at height $\mathrm{AB}$, the $\mathrm{BC}$ and $\mathrm{FB}$ shading lengths of the rays are obtained with the following relations (Anderson and Mikhail, 1998; Bannister et al., 1998).

$\mathrm{BC}=\mathrm{AB} / \tan \mathrm{y}_{1}=\mathrm{AB} * \tan \mathrm{z}_{1}$

$\mathrm{FB}=\mathrm{AB} / \tan \mathrm{y}_{2}=\mathrm{AB} * \tan \mathrm{z}_{2}$

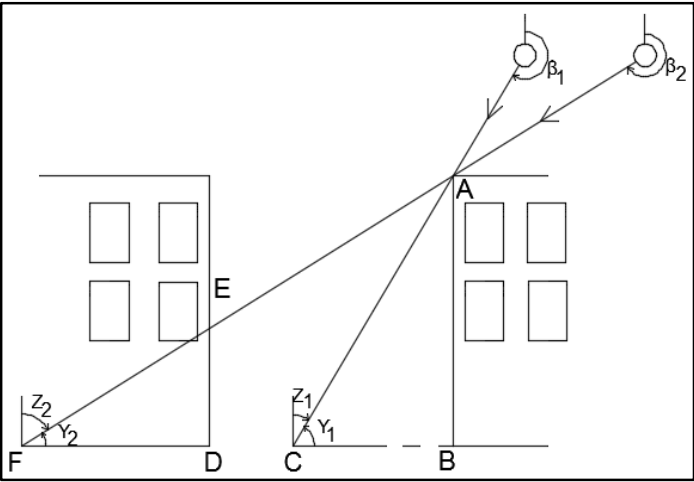

Figure 3 - Shading lengths of the sun's rays that come at different times in sunny weather on the ground and neighboring building surfaces

Here,

FB: The length of the shade on the floor in line with

FA (in the direction of the $\beta 2$ solar azimuth angle)

DB: horizontal length between neighboring buildings calculated by correlation (7) or (8) or (9) or (10)

FD: Shading length at the base of the neighboring building in the shading direction

$\mathrm{ED}$ : In the case of $\mathrm{FB}>\mathrm{DB}$, the height of the shading of the $\mathrm{AB}$ wall on the surface of the neighboring building.

FD and ED are obtained with the following relations:

$\mathrm{FD}=\mathrm{AB} * \operatorname{tanz}_{2}-$ (The length obtained by the relationship between (7) or (8) or (9) or (10))

$\mathrm{ED}=\mathrm{FD} * \tan \mathrm{y}_{2}$

The building wall in a parcel must be FB > DB to form a shading on the surface of the building in the neighboring parcel.

If $\mathrm{FB}<\mathrm{DB}$, then the shading of the building exposed to the sun is formed in the neighboring garden area or the back-garden area between the neighboring buildings (Arumi-Noe, 1996; Data, 2001; (Kuşak and Küçükali, 2019)).

For $\mathrm{h}=0$, the shadings of the objects are not formed since the sun's rays come in a direction perpendicular to the earth, so the sun angles between $\mathrm{h}= \pm 1$ and $\mathrm{h}= \pm 6$ were used in the calculations.

According to the issues described above; The length of the shading formed in a 5-storey building structure, area of neighboring gardens, area of back gardens and area of front gardens (or side gardens) in a zoning parcel, as well as the height of the shade on the neighboring building surface, are shown in Figures 4 through 11. 


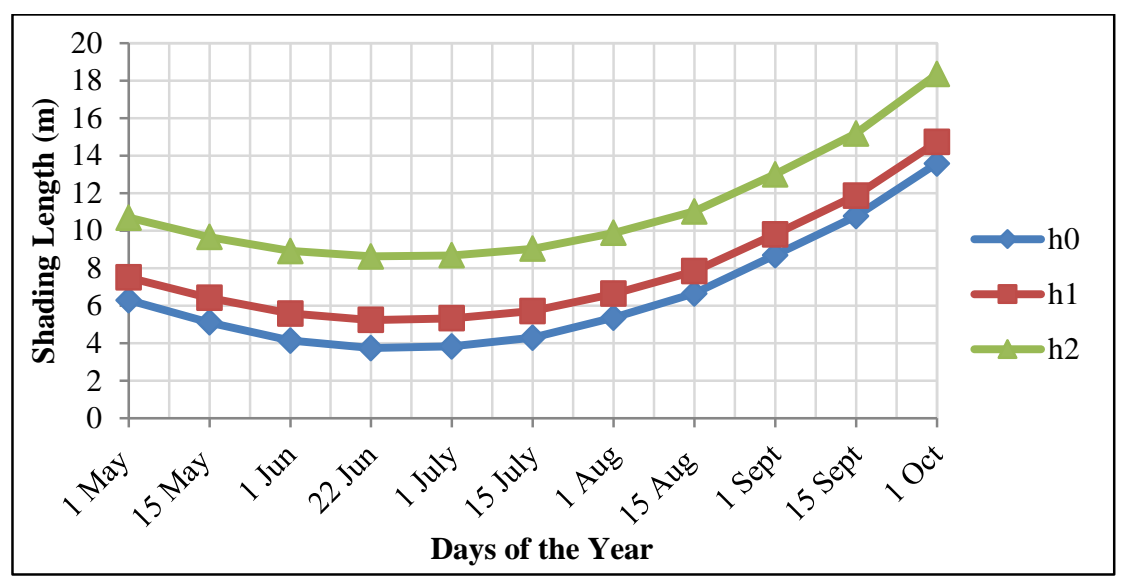

Figure 4- Length of Shading in Neighborhood Garden Areas According to the Months and Sun Hours (in m units).

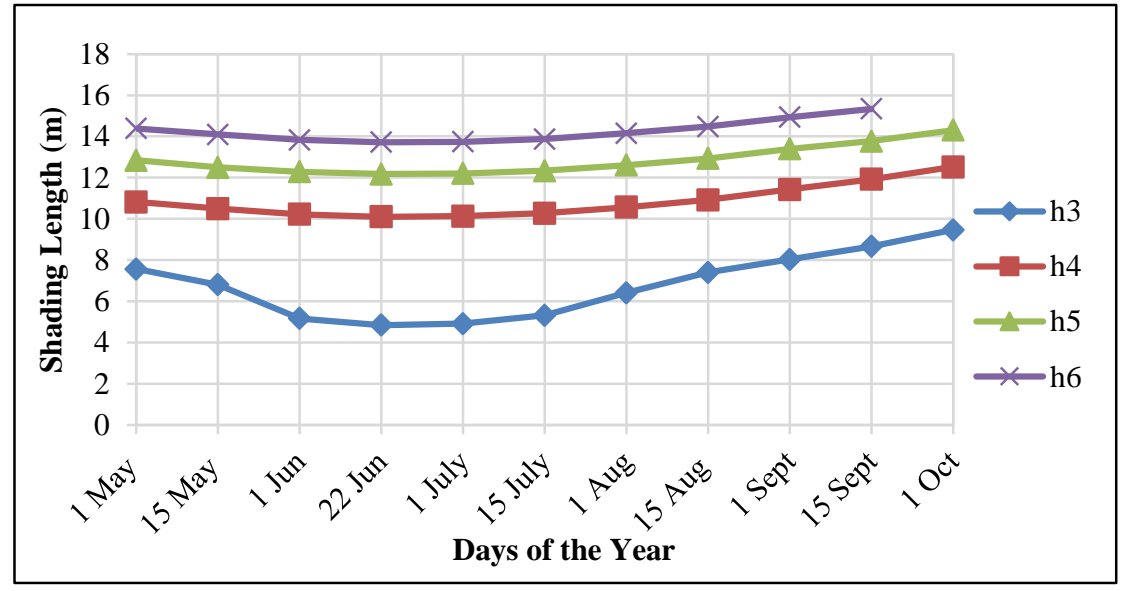

Figure 5- Shade Length According to Sun Hours and the Months on the Building Surface in the Neighborhood Garden (in $m$ units)

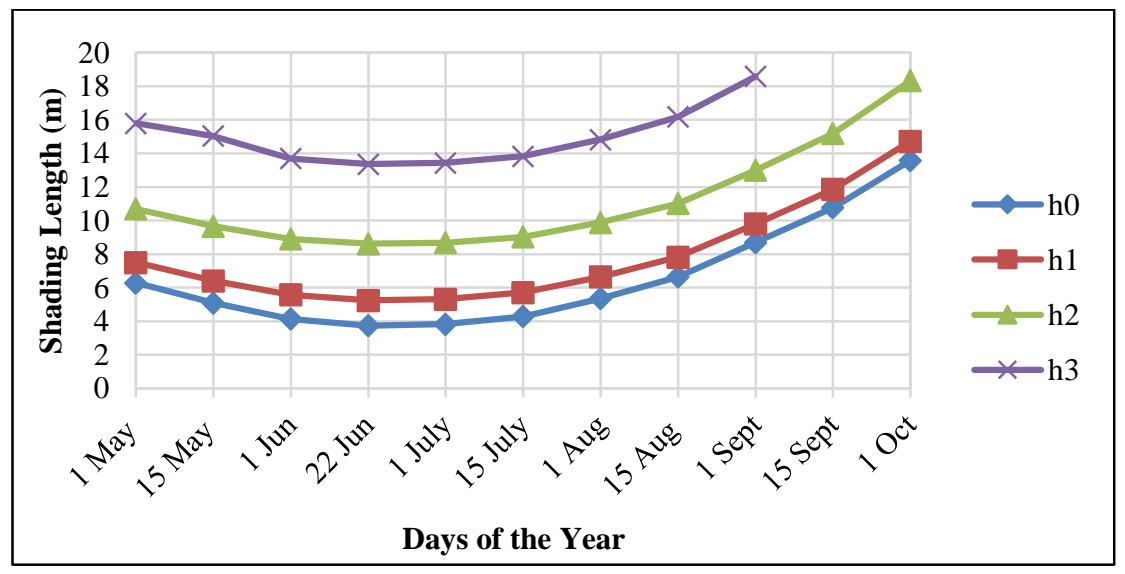

Figure 6- Shade Length in the back garden area according to Sun Hours and the Months (in m units) 


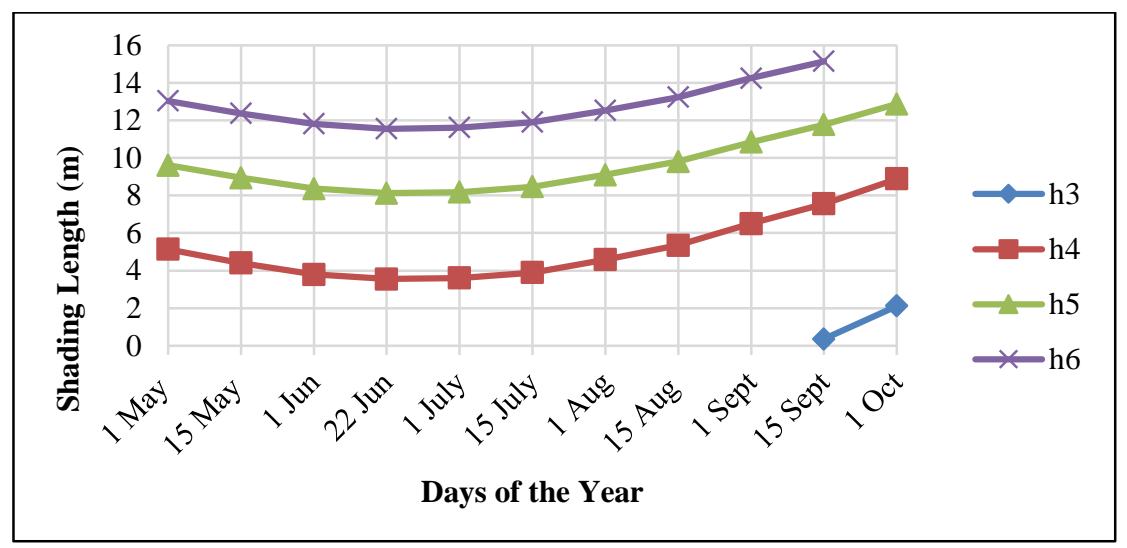

Figure 7- Shading Length in the neighboring building surface in the back garden according to Sun Hours and the Months (in $\mathrm{m}$ units)

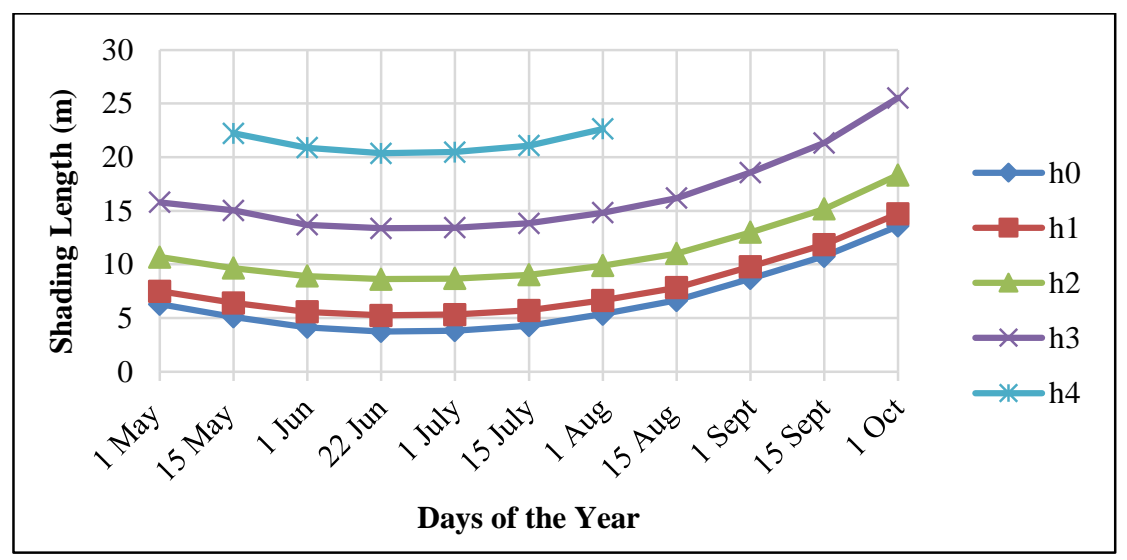

Figure 8- Shading Length in the front garden areas according to Sun Hours and the Months (in m units)

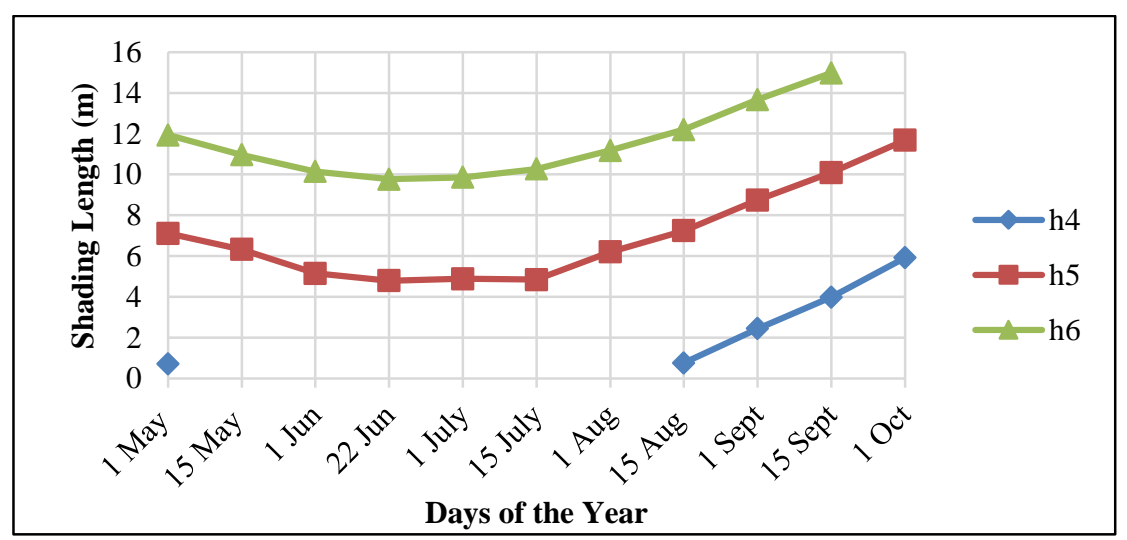

Figure 9- Shading Length in the building surface of the front neighboring garden according to Sun Hours and the Months (in $\mathrm{m}$ units) 


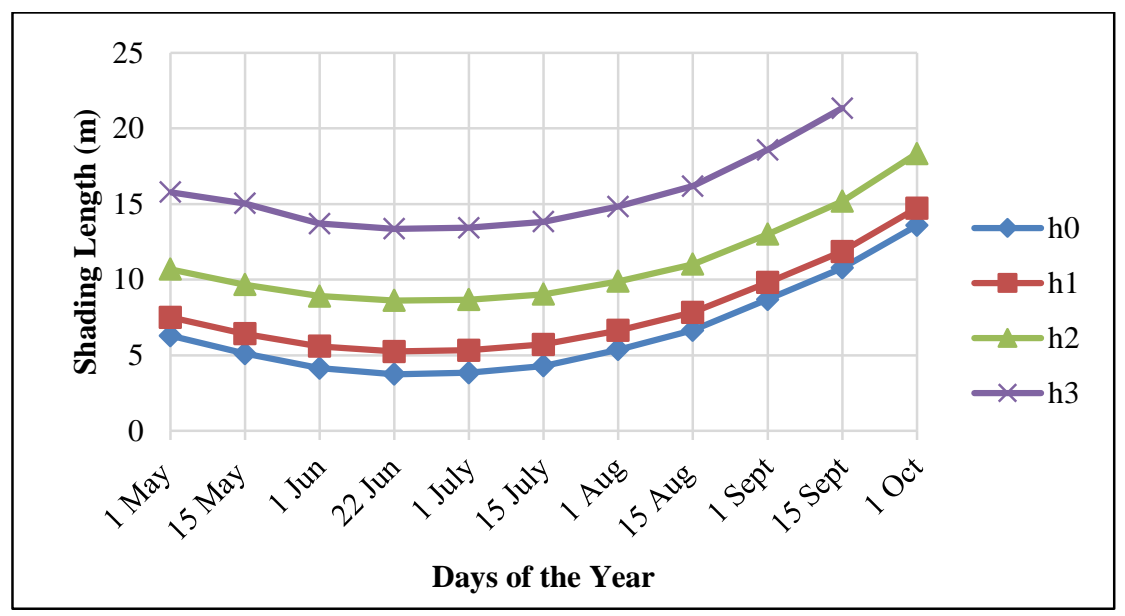

Figure 10-Shade Length in the field of side gardens according to Sun Hours and the Months (in m units)

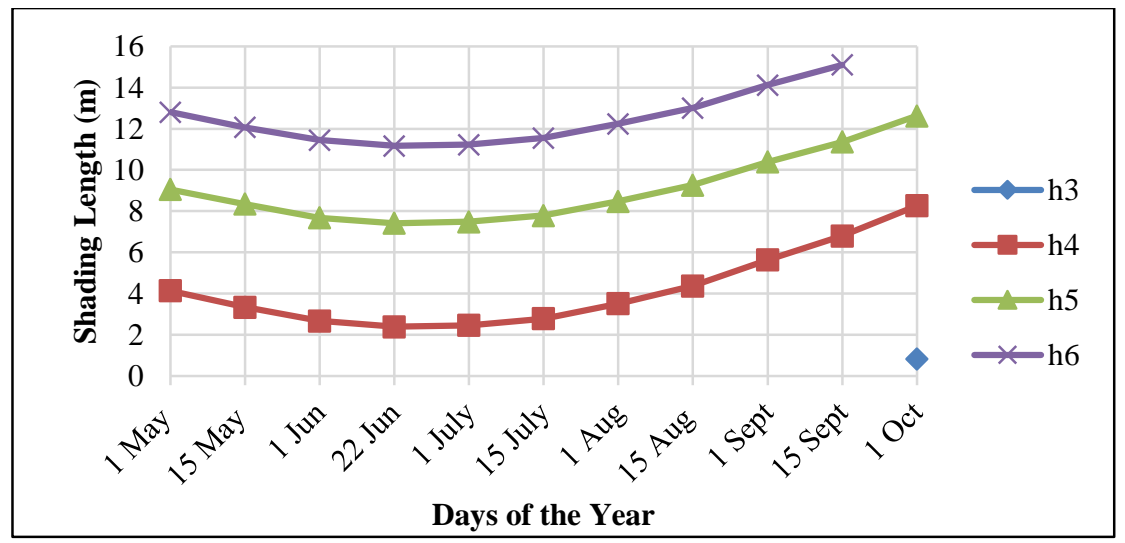

Figure 11- Shading length in the building surface in the side garden according to Sun hours and the Months (in m units).

\section{INVESTIGATION OF BUILDING POSITION IN ADJACENT ISLAND AND PARCEL SUITABLE FOR SHADING}

For construction in a settlement area, the azimuth angles of the district lines of the reconstruction island may have various values (Szokolay, 1980; Al-Sareef et al., 2001; Tavares and Martins, 2007; Selim and Demir, 2019; Ekercin et al., 2019). The values of this specified angle may be in practice $0 \mathrm{~g}$ (or 200), $50 \mathrm{~g}$ (or $250 \mathrm{~g}$ ), $100 \mathrm{~g}$ (or $300 \mathrm{~g}$ ), $150 \mathrm{~g}$ (or $350 \mathrm{~g}$ ) or fractional values.

If the façade of a building and the zoning parcel, the island where the sun will be used during the day is positioned according to $50^{\mathrm{g}}$ to $250^{\mathrm{g}}$ of the solar azimuth angles.

- The parcel area to be calculated according to the building façade, the building depth and the garden distance given in the project are at minimum values.

- In terms of space saving, for the parcel or island façade to be created, where the solar azimuth angles $50 \mathrm{~g}-150 \mathrm{~g}$ or $150 \mathrm{~g}-250 \mathrm{~g}$ should be positioned according to a research on the subject requires information (İnce \& Erdem, 2018).

In order not to sunbathe during a day in a building on a zoning island, it must be closely examined whether the azimuth angle of the reconstruction island façade is $0 \mathrm{~g}$ or $100 \mathrm{~g}$, that is, in the north-south direction or west-east direction of the zoning island front line (Fig. 12 and Fig. 13).

When the situation before the local afternoon in Figure 12 is examined between May 1 and October 1 of the year, the following issues may be mentioned:

- Between the hours $h=0$ and $h=-5$, the façades of all buildings in the parcels facing north and west remain in the shade, and the façades of the buildings facing east are under the influence of the sun.

- Between the hours $h=-3$ and $h=-5$, the southern façades of the buildings on the zoning island are under the influence of the sun.

When the situation after the local afternoon in Figure 12 is examined between May 1 and October 1 of the year, the following may be mentioned:

- The façades of the west-facing buildings of the zoning islands are exposed to the sun between $h=0$ and $h=5$, and the eastern and northern façades of the buildings are over-shaded. 
The shade lengths on the east side façades and adjacent garden areas of the buildings located from the right to the left after the buildings to the east of the reconstruction island between the morning and the local noon are shown in Figure 4.

The shading lengths on the west side façades and adjacent garden areas of the buildings located from the left to the right after the buildings to the west of the reconstruction island are shown in Figure 5.

The $\mathrm{h}= \pm 4$ shade length is $10.82 \mathrm{~m}$ on 1 May, while it decreases to $10.10 \mathrm{~m}$ on June 21 and increases to $12.52 \mathrm{~m}$ on 1 October.

The shade length at $\mathrm{h}= \pm 5$ is $12.84 \mathrm{~m}$ on May 1 and 12.17 $\mathrm{m}$ on 21 June, and it rises to $14.31 \mathrm{~m}$ on 1 October.

The shade length at $\mathrm{h}= \pm 6$ decreases to $13.72 \mathrm{~m}$ on June 21, $14.39 \mathrm{~m}$ on 1 May and $15.34 \mathrm{~m}$ on 15 September.

The shadings formed between $\mathrm{h}=0$ and $\mathrm{h}= \pm 2$ are located in the neighboring garden areas between the buildings. Between $\mathrm{h}=0$ and $\mathrm{h}= \pm 3$, the shadings remain in the backyard areas (Figures 4-6). Shading length generated: $7.74 \mathrm{~m}$ to $18.34 \mathrm{~m}$ in the neighboring garden areas and $6.29 \mathrm{~m}$ to $18.58 \mathrm{~m}$ in the backyard areas (Figures 4-6).

- At $\mathrm{h}= \pm 6$ solar hour, the north facing façades of all buildings in the plots are under the influence of the sun rays coming from the side.

- Between the hours of $h=0$ and $h= \pm 5$, the façades of the buildings facing north, where the southern façades of the buildings on the zoning island are under the influence of the sun, are over-shaded.

The shadings between $\mathrm{h}= \pm 3$ and $\mathrm{h}= \pm 6$ create shading lengths of $4.84 \mathrm{~m}$ to $15.53 \mathrm{~m}$ on the building surface of the neighboring garden and $3.55 \mathrm{~m}$ to $15.15 \mathrm{~m}$ on the building surface in the backyard (Figures 5-7).

When Figure 13 is examined, it may be observed that the issues mentioned in Figure 12 apply here.

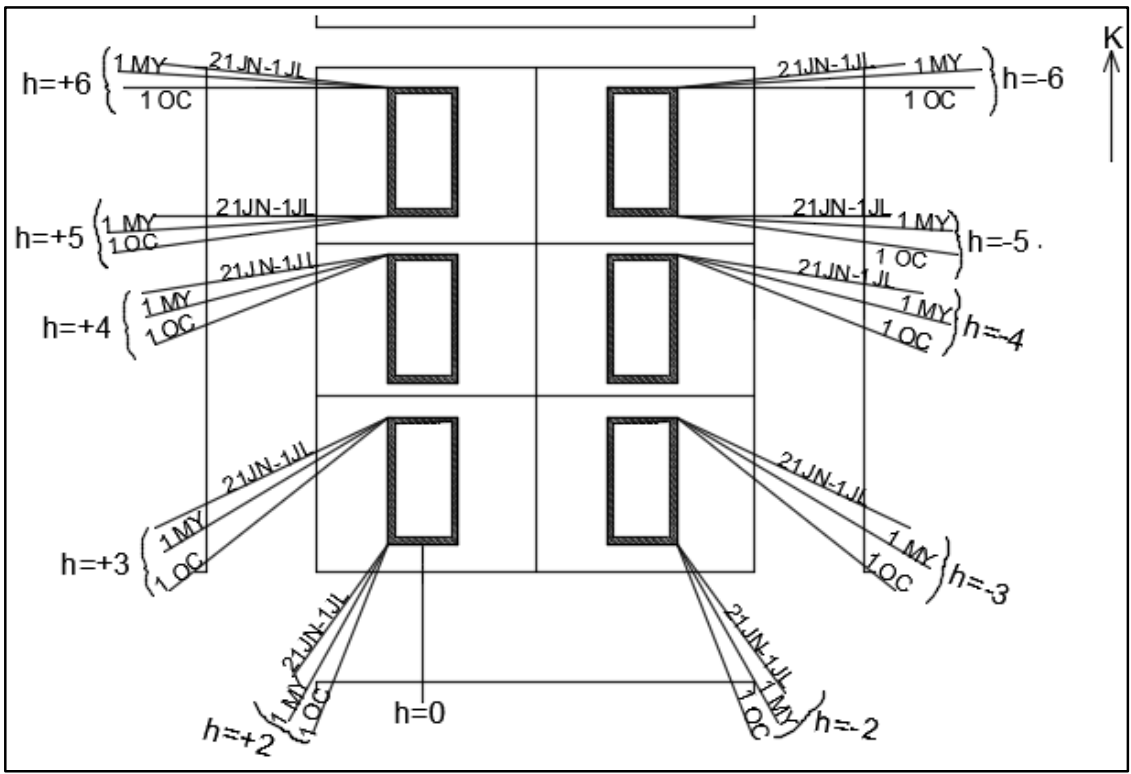

Figure 12-Shading-brightness effects of sun rays in buildings at various values of the solar azimuth angle when the façade of the reconstruction island is in the north-south direction (JN: June, JY: July, MY: May, OC: October). 


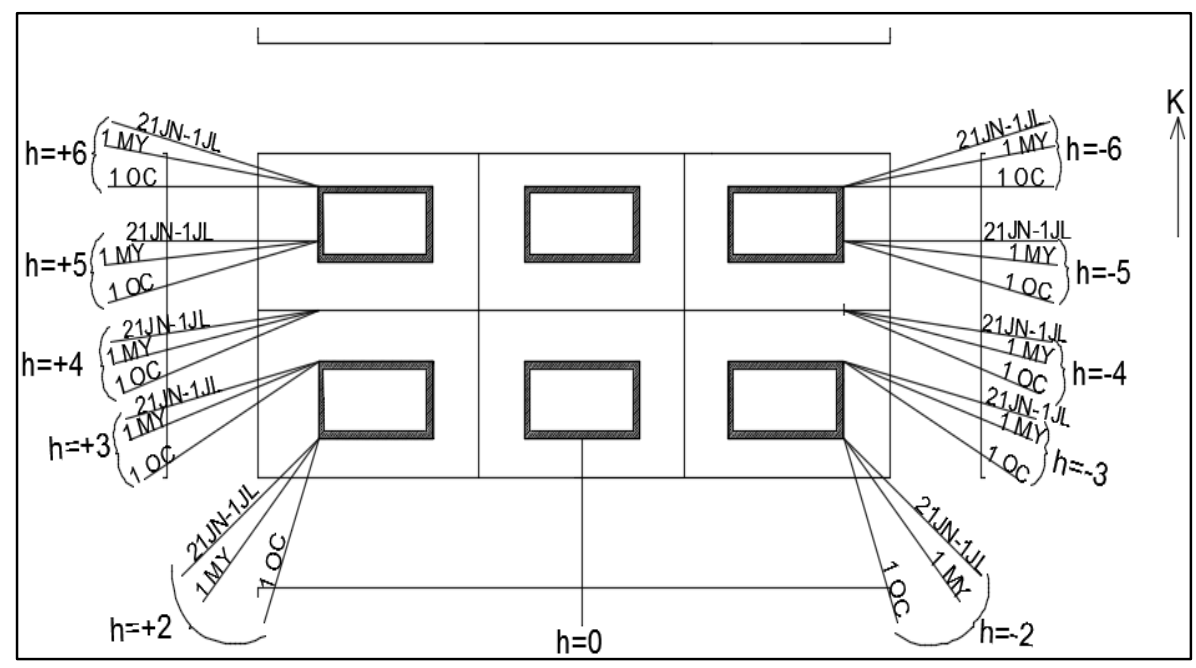

Figure 13-Shading- brightness effects of solar rays on buildings at various values of the solar azimuth angle when the façade of the reconstruction island is in the west-east direction.

\section{DISCUSSION}

If the front and rear façades of buildings are positioned in the west-east direction between May 1 and October 1, the following situations may be considered:

- At $\mathrm{h}= \pm 6$, the façades of the buildings facing north in the parcels are under the influence of the sun rays coming from the side, and the rear façades of the buildings are in the shade.

- Between $\mathrm{h}= \pm 3$ and $\mathrm{h}= \pm 5$, the side façades of the buildings in the parcels, which are generally closed, and the south facing façades of the buildings are exposed to sunlight. The façades of the buildings facing north (the façades of the buildings located in the north of the zoning island and the façades of the buildings in the south of the zoning island) remain in the shade.

- Between the $\mathrm{h}=0$ and $\mathrm{h}= \pm 2$, the south facing façades of the buildings in the zoning island are exposed to sun rays. The north-facing façades of the buildings remain in the shade.

Between 1 May and 1 October, when the front and rear façades of the buildings are positioned in the north-south direction, the following conditions occur:

- At $\mathrm{h}= \pm 6$, the north side of the buildings in the parcels and the generally closed side façades are under the influence of the sun rays coming from the side. The façades of the buildings and the south-facing façades are in the shade.

- Between $h= \pm 3$ and $h= \pm 5$, the façades of the buildings in the parcels and the south-facing side façades are exposed to sunlight, and the back façades of the buildings are in the shade.

- Between $h=0$ and $h= \pm 2$, the south-facing façades of the buildings in the parcels, i.e. the buildings in the south of the island, are exposed to sunlight. The north-facing façades of the buildings are in the shade.
If the front and back façades of the buildings are located in the west-east direction, according to the positioning of the buildings in the north-south direction, the front and back façades are exposed to less sun hours and more shade (Van Moeseke et. al., 2007).

\section{CONCLUSIONS}

1-From 1 May to 1 October in sunny weather, depending on the solar azimuth angle and the solar height of the sun, the lengths of the shadings formed by the buildings in the discrete structure of a zoning island in Adana are described below:

a-The shadings are formed between the $\mathrm{h}=0$ and $\mathrm{h}= \pm 2$ sun hours in the neighboring garden areas and between the $h= \pm 3$ and $h= \pm 6$ sun hours on the surfaces of the neighboring parcel.

b-The shadings are formed between the $\mathrm{h}=0$ and $\mathrm{h}= \pm 3$ sun hours in the backyard areas and the $\mathrm{h}= \pm 4$ and $\mathrm{h}= \pm$ 6 sun hours on the building surfaces in the rear parcel.

c-The shadings are formed between $\mathrm{h}=0$ and $\mathrm{h}= \pm 3$ in the front yard areas and $h= \pm 4$ and $h= \pm 6$ sun hours on the building surfaces in the rear parcel.

$\mathrm{d}$ - The shadings are formed precisely between $\mathrm{h}=0$ and $\mathrm{h}= \pm 3$ in the front yard areas and partly at $\mathrm{h}= \pm 4 \mathrm{~h}$ (between May 15 and August 1 ) between $\mathrm{h}= \pm 5$ and $\mathrm{h}=$ \pm 6 and at $\mathrm{h}= \pm 4$ hours (May 1, August 15 to October 1 ).

2-The shading length changes in the sun hours mentioned above are described below:

a-The length of the shading formed in the neighboring garden areas is between $3.74 \mathrm{~m}$ and $18.34 \mathrm{~m}$. The length of the shading formed on the adjacent building surfaces is $4.91 \mathrm{~m}$ to $15.34 \mathrm{~m}$ from the ground.

b-The length of the shading formed in the backyard areas is between $3.83 \mathrm{~m}$ and $18.58 \mathrm{~m}$. The length of the shading formed on the rear building surfaces is $3.55 \mathrm{~m}$ to $15.14 \mathrm{~m}$ from the ground. 
c-The length of the shading formed in the front yard areas is between $3.74 \mathrm{~m}$ and $25.33 \mathrm{~m}$. The length of the shading formed on the rear building surfaces is $0.71 \mathrm{~m}$ to $14.98 \mathrm{~m}$ from the ground.

d-The length of the shading formed in the side garden areas is between $3.83 \mathrm{~m}$ and $18.58 \mathrm{~m}$. The height of the shading formed on the rear building surfaces is $2.67 \mathrm{~m}$ to $15.10 \mathrm{~m}$.

3-If the front and rear façades of the buildings are located in the west-east direction, according to the positioning of the buildings in the north-south direction, the front and rear façades are exposed to less sun hours and more shade.

4-If the front and rear façades of the buildings are located in the west-east direction, the following points arise:

a- At $\mathrm{h}= \pm 6$, the façades of the buildings in the parcels facing north are under the influence of the sun rays coming from the side, and the rear façades of the buildings are in the shade.

b-Between $\mathrm{h}= \pm 3$ and $\mathrm{h}= \pm 5$, the façades of the buildings, which are generally without windows, and the south facing façades are exposed to sunlight. The façades of the buildings facing north (the façades of the buildings located in the north of the zoning island, the façades of the buildings in the south of the zoning island) remain in the shade.

c- Between $h=0$ and $h= \pm 2$, the south-facing façades of the buildings in the parcels, i.e. the buildings in the south of the island, are exposed to sunlight. The north-facing façades of the buildings are in the shade.

\section{REFERENCES}

Abood, A. A. (2015), "A Comprehensive solar angles simulation and calculation using Matlab", International Journal of Energy and Environment (IJEE), Volume 6, Issue 4, pp. 367-376.

Al-Sareef, F. M., Oldham, D. J., Carter, D. J. (2001), “A computer model for predicting the daylight performance of complex paralel shading systems," Building and Environment, n: 36; 605-18.

Anderson, J.M. and Mikhail, E.M. (1998), "Surveying theory and practice", 7th ed. Boston, MA: Mc Graw Hill.

Arum1-Noe, F. (1996), "Algorithm for geometric contruction of an optimum shading", Automation in Construction, n: 5; 211-7.

Atabek, E. (1996), "Computer aided shadowing effect analysis of buildings", Yüksek Lisans Tezi, Mimarlık Bölümü, ODTÜ, Ankara.

Bannister, A., Raymond, S. and Baker, R. (1998), "Surveying". 7th ed. Harlow, UK: Addison Wesley Longman Limited Edinburg Gate, 81-82.
Capeluto, G.I., Yezioro, A., Shaviv, E. (2003), "Climatic Aspects in Urban Design: A Case Study", Building and Environment, Vol.38, Issue 6, pp.827-83.

Data G. (2001), "Effect of fixed horizontal louver shading devices on thermal performance of building by TRNSYS simulation”, Renewable Energy, n: 23; 497-507.

Erdem, N., and İnce, H. (2016), "The Proposal Of The Building Application For More Benefiting From Solar Light", International Journal of Engineering and Geosciences, 1 (1), 7-14. DOI: 10.26833/ijeg.285215

Ekercin, S, Orhan, O, Dadaser-Celik, F. (2019), "Investigating Land Surface Temperature Changes Using Landsat-5 Data And Real-Time Infrared Thermometer Measurements at Konya Closed Basin in Turkey", International Journal of Engineering and Geosciences, 4 (1), 16-27. DOI: 10.26833/ijeg.417151

Farr, D. (2008), "Sustainable Urbanism: Urban Design with Nature", Wiley, New Jersey.

Kuşak, L, Küçükali, U. (2019), "Outlier Detection of Land Surface Temperature: Küçükçekmece Region", International Journal of Engineering and Geosciences, 4 (1), 1-7. DOI: $10.26833 /$ ijeg.404426

İnce, H., and Erdem, N. (2018), "Gün Işı̆̆ından Azami Yararlanacak Şekilde Yapılacak Binalar İçin Alan Tasarrufu Bakımından Parsel Konumunun Araştırılması", Mühendislik Alanında Akademik Araștırmalar, ISBN.978-605-288-390-7, www.gecekitapligi.com, s.143-161, Ankara.

Mcmullan, R. (1990), "Environmental Science in Building”, Macmillan, Hong Kong.

Ok, V. (1992), “A procedure for calculation cooling load due to solar radiation: the shading effects from adjacent or nearby buildings", Energy and Buildings, Vol.19, 11 20.

Oktay, D. (2004), "Urban Design for Sustainability: A Study on the Turkish City", International Journal of Sustainable Development and World Ecology, 11/1, March, 24-35.

Olgyay, V. (1957), "Solar Control and Shading Devices", Princeton University Press, Princeton.

Selim, S, Demir, N. (2019), "Detection of Ecological Networks and Connectivity With Analyzing Their Effects on Sustainable Urban Development", International Journal of Engineering and Geosciences, 4 (2), 63-70. DOI: $10.26833 / \mathrm{ijeg} .443114$

Soler, A., Oteiza, P. (1997), "Light self-performance in Madrid, Spain", Building and Environment, (32:2) 87-93.

Som, T. and Pathak, R. (2015), "Maximum Solar Power Generation through Optimization of Tilt Solar Angles of Solar Panels by Heuristic Technique", International Journal of Innovative Research in Electrical, Electronics, 
Instrumentation and Control Engineering, DOI 10.17148/IJIREEICE.2015.3409, Vol. 3, Issue 4, April.

Szokolay, S.V. (1980), "World Solar Architecture", John Wiley and Sons Inc, New York.

Tavares, P.F.A.F. and Martins, A.M.O.G. (2007), "Energy Efficient Building Design Using Sensitivity Analysis: A Case Study", Energy and Buildings, Vol.39, pp.23-31.

Van Moeseke, G., Bruyère I., De Herde, A. (2007), "Impact of control rules on the efficiency of shading devices and free cooling for office buildings", Building and Environment (42:2) 784-93.
Yeang, K. (1995), "Design with Nature: The Ecological Basis for Architectural Design", McGraw-Hill, New York.

Yüceer, N. S. (2010), “Gölge Elemanı Tasarımına Bir Yaklaşım Ve Adana Örneği”, METU JFA 201/2, 27:2 13, DOI:10.4305/METU.JFA.2010.2.1, s.1-12,

Yüceer, N. S. (2011), “Gölgelenme Elemanlarının Önemi ve Adana Üzerine Bir Deneme", Ekoloji Mimarlık, Güney Mimarlık, TMMOB Mimarlar Odası Adana Şubesi Yayını, sayı 6, s. 54-56, Adana 